\title{
Religious Education Practices in Pesantren: Charismatic Kyai Leadership in Academic and Social Activities
}

\author{
Naufal Ahmad Rijalul Alam ${ }^{a}$ \\ a) Universitas Muhammadiyah Yogyakarta, ORCID iD https://orcid.org/0000-0003-2793-6119
}

\section{ABSTRAK}

Penelitian ini mengungkap praktik pendidikan agama melalui karakteristik kepemimpinan Kyai sebagai pengambil keputusan sekaligus pengasuh di pesantren. Data penelitian kualitatif ini diperoleh melalui dokumentasi, observasi, dan wawancara di Pesantren Bina Insani Yogyakarta. Pendidikan di pesantren Bina Insani selama ini dikenal sebagai pendidikan berbasis masyarakat yang bersumber dari aspirasi masyarakat, sekaligus untuk memenuhi kebutuhan mereka. Sebagai lembaga pendidikan berbasis masyarakat, pesantren sangat bergantung pada inisiatif dan karisma kyai yang menjadi pemimpinnya. Hasil penelitian menunjukkan bahwa karakteristik kepemimpinan karismatik Kyai Teguh menjadi tolok ukur tidak tertulis bagi pihak-pihak di bawah naungannya dalam mengelola pesantren dan dalam mengembangkan kecakapan sosial. Dalam perspektif teori kepemimpinan, sosok Kyai Teguh telah menjadi landasan rasional bagi pengikutnya dalam pengambilan keputusan, etos kerja, dan pola interaksi sosial.

\section{ABSTRACT}

This study investigates religious education practices through Kyai leadership characteristics as the caregiver as well as a decision-maker in pesantren. qualitative data are gathered through documentation, observation, and interview at Pesantren Bina Insani, Yogyakarta. The education at Pesantren Bina Insani has been well known as community-based education, derived from the aspirations of the community, and to meet their interests. As a community-based educational institution, the Pesantren is very dependent upon the initiative and charisma of the Kyai as the leader. The results demonstrate that Kyai Teguh's charismatic leadership characteristics have turned into unwritten standards for people under his influence in managing the Pesantren and developing their social skills. From leadership theory perspective, Kyai Teguh's characteristics are the rational grounds for his followers in terms of decision making, wok-ethics, and social interactions.

\section{KATA KUNCI}

Pendidikan agama;

Kepemimpinan Karismatik; Kyai;

Kinerja; Kegiatan akademik ;

Kegiatan Sosial.

\section{A. Introduction}

Leadership is primarily an individual's ability to develop, guide, direct and inspire others to wor $\mathrm{k}$ together to set targets. ${ }^{1}$ To achieve these goals, leaders must undertake a series of activities including directing the people involved in the organization they are leading. In other words, it depends on its

\footnotetext{
${ }^{1}$ Fred E. Fiedler, A Theory of Leadership Effective (New York: Mc. Gwar-Hill Book Company, 1964); C. F. Achua and R. N. Lussier, Effective Leadership, 5th ed. (Ohio: South Western, 2013); T. A. Judge, R. F. Piccolo, and T Kosalka, "The Bright and Dark Sides of Leader Traits: A Review and Theoretical Extension of the Leader Trait Paradigm," The Leadership Quarterly 20 (2009): 855-875.

CONTACT Naufal Ahmad Rijalul Alam $\square$ naufal.ahmad@umy.ac.id $\square$ Jl. Brawijaya, Tamantirto, Kasihan, Bantul, Yogyakarta, 
Naufal Ahmad Rijalul Alam

management whether the aims of an organization are accomplished. Shamir, et $\mathrm{al}^{2}$ who stated charismatic leadership at an organization brings positive influence for the sustainability of that organization led, which can change attitudes, values, and behavior of members consistent. Finally, the values are delivered that later affect the emotions of the members, so these values are applied by para its members. Charismatic leadership is a type of leadership that can influence the values of its members. This type has a characteristic to articulate the ideology values through better organizational vision. ${ }^{3}$

The circumstances are occurring to the Indonesian schools, including madrasah and pesantren which have organizations and systems to guard the academic and non-academic values. Teachers teach and work in schools that are generally run by supervisors, often referred to as headmasters or directors of the school. The administration of the school itself can be part of a larger organizational structure. Teacher working conditions are determined by the administration and leadership provided by the principal, and school leadership is generally believed to directly influence teacher performance and student achievement outcomes. ${ }^{4}$

As an organization, educational institutions need not only a manager to manage the resources of educational institutions that concentrate more on budget issues and other administrative issues, but also need a leader who is able to create a vision and all the individual components associated with educational institutions. ${ }^{5}$ Leaders and managers are needed in the management of educational institutions. Unlike other organizations, educational institutions are a form of moral organization that is different from other forms of organization. ${ }^{6}$ Indeed, the success of educational institutions is not only determined by the leadership of education, but also by other education personnel and the process of the educational institution itself. ${ }^{7}$ Educational leadership is obliged to coordinate education personnel in educational institutions to ensure the application of regulations to educational institutions.

\footnotetext{
${ }^{2}$ Boas Shamir, Robert J. House, and Michael B. Arthur, "The Motivational Effects of Charismatic Leadership : A SelfConcept Based Theory," Organization Science 4, no. 4 (1993): 577-594.

${ }^{3}$ Andre Delbecq et al., "Implicit Motives, Leadership, and Follower Outcomes: An Empirical Test of CEOs," Journal of Leadership and Organizational Studies 20, no. 1 (2013): 7-24.

${ }^{4}$ JoAnn Bartoletti and Gail Connelly, Leadership Matters: What the Research Says About the Importance of Principal Leadership, National Association of Secondary School Principals and National Association of Elementary School Principals (Virginia, 2013); A. Blumberg and W. Greenfield, The Effective Principal: Perspectives on School Leadership (Boston: Allyn and Bacon, Inc, 1980); Emily Ayscue Hassel and Bryan C. Hassel, "An Excellent Principal for Every School," Public Impact (2016): 1-16.

${ }^{5}$ Gamal Abdul Nasir Zakaria, "Pondok Pesantren: Changes and Its Future," Journal of Islamic and Arabic Education 2, no. 2 (2010): 45-52; Mlchael A. Peters, Encyclopedia of Educational Philosophy and Theory, Encyclopedia of Educational Philosophy and Theory, 2017, http://link.springer.com/10.1007/978-981-287-588-4.

${ }^{6}$ Muhamad Ramli, “Manajemen Dan Kepemimpinan Pesantren: Dinamika Kepemimpinan Kiai Di Pesantren," Al Falah 17, no. 2 (2017): 125-162; Achmad Zainal Arifin, "Charisma and Rationalisation in a Modernising Pesantren : Changing Values in Traditional Islamic Education in Java" (2013): 97, http://researchdirect.uws.edu.au/islandora/object/uws\%3A17130/; Naufal Ahmad Rijalul Alam, "Strengthening Leadership Culture: The Role of Kyai in Indonesian Pesantren," At-Ta'dib 13, no. 1 (2018): 5-17.

${ }^{7}$ Peters, Encycl. Educ. Philos. Theory; Syamsuriadi, "Self Management Concept Dalam Kepemimpinan Lembaga Pendidikan," Adaara: Jurnal Manajemen Pendidikan Islam 9, no. 2 (2019): 871-879; Nigel Bennett and Lesley Anderson, Rethinking Educational Leadership: Challenging the Conventions (SAGE Publications, 2003).
} 
In the Indonesian context, as the formal institution, pesantren -the oldest Islamic education in Indonesia- has a unique characteristic that is not shared by other educational institutions. Sociologically the emergence of pesantren is the result of engineered individuals who feel competent to transmit religious education and Islamic teachings that are economically well-established, so naturally the development of pesantren is strongly colored by Kyai who nurture it. ${ }^{8}$ Therefore, all aspects need to be explained. There are at least five aspects that can be studied from pesantren: educative aspects, cultural aspects, political aspects, economic aspects, and aspects of leadership. ${ }^{9}$ There is a very close relationship between the kyai and the santri. Students see the kyai as a central figure to obey both their guidance and suggestions, even such obedience has become a rule in pesantren. Pesantren's leadership is one of several aspects of the pesantren.

This research is important to examine because pesantren, as a formal education institution, has a clear organizational structure like school in general. The difference lies in Kyai's character as a leader as well as the leader of the pesantren who oversees all activities, both academic and non-academic, and in his ability to coordinate, communicate, influence his followers to understand and doing what he said. The difference between this study and previous research lies in three aspects: 1) the location of the pesantren, where the focus is to reveal the practice of Kyai leadership in managing pesantren in rural areas, 2) social activities carried out, not only in the field of religion but also in the other field and 3) making the community around the pesantren as partners in social activities.

In specific, this paper attempts to investigate the level to which the pesantren was raised by the leadership of the Kyai. So, the study has objectives and focuses on 1) how is the practice of religious education in the Bina Insani pesantren, and 2) what are the characters of the charismatic leadership of Kyai in carrying out the academic and social activities. In answering those two questions, I used a phenomenological qualitative approach. There are three data collection methods that I used: observation, documentation, and the in-depth interview with ten respondents from pesantren who has been led by Kyai Teguh since 2005. For this interview, I used an initial from respondents to these forms: R1, R2, R3, R4, R5, R6, R7, R8, R9, and R10.

To obtain measured data, I used tests of data credibility by research extension and source triangulation by interviews. Data analysis employed the theory of Miles and Huberman, ${ }^{10}$ where I

\footnotetext{
${ }^{8}$ Muhamad Ahsan et al., "Developing Entrepreneurial Spirit Based on Local Wisdom," International Journal of Social Science Research 4, no. 2 (2016): 44; Bambang Winarko, "Content, Benefits and Development of Pesantren Online in Indonesia," Malaysian Journal of Library \& Information Science 12, no. 2 (2007): 57-75.

${ }^{9}$ Abdullah Sahin, "Critical Issues in Islamic Education Studies: Rethinking Islamic and Western Liberal Secular Values of Education," Religions 9, no. 11 (2018); Soleh Subagja, "PARADIGMA NILAI-NILAI KEPEMIMPINAN PROFETIK (Spirit Implementasi Model Kepemimpinan Di Lembaga Pendidikan Islam)," Progresiva 3, no. 2 (2010): 23-42; Siti Muflichah, "The Charisma Leadership Style of Kyai Haji Arwani Amin The Founder of Yanbuul Quran Pesantren, Kudus," Journal of Islamic Civilization in Southeast 03, no. 01 (2014): 61-81, http://journal.uinalauddin.ac.id/index.php/jicsa/article/view/774.

${ }^{10}$ Matthew B. Miles, A. Michael Huberman, and J. Saldana, Qualitative Data Analysis: A Method Sourcebook, 3rd ed. (USA: SAGE Publications, 2014).
} 
Naufal Ahmad Rijalul Alam

collected data from respondent's interview. Later, data was reduced into several categories. After obtaining data suitable with an instrument having been designated, then I present data of research's finding descriptively, focusing on interpretation resident's perspective on Kyai's leadership. The following step provided the conclusion of the research's findings and discussions.

\section{B. Pesantren and Theory of Charismatic Leadership}

The scholars put forward a lot of the definition of pesantren in terminology. In short, pesantren is an Indonesian Islamic educational institution that practices Islamic teaching by emphasizing the importance of religious morals as guidelines for daily behavior, in which there are 24-hour interactions between Kyai, Ustadz as teachers and students as students by taking place in mosques, classes, or boarding yards. ${ }^{11}$ The pesantren has been one of the community-based educational institutions that developed around the area of the homes of the citizens to improve contact and cooperation between the residents of pesantren and the government, both in religious and public affairs. Pesantren has five key elements as a unique educational institution in Indonesia, namely: dormitories, mosques, Santri, teaching Arabic and Classical Books, or popularly known as the Yellow Book (turats), Kyai, and Ustadz (teacher).

The dormitory of the pesantren tradition is an essential element that must be present. Pondok is a hostel where students live together to study under the guidance of the Kyai. In general, dormitories in the form of a complex surrounded by a fence as a barrier that separates the community environment. But some are not limited, even sometimes mingle with the community environment. Although different in terms of form, and funding for the construction of the boarding school in each pesantren, there is a general similarity, namely absolute authority and power over the construction and management of the boarding school held by the Kyai who heads the pesantren.

The mosque is a factor that cannot be detached from the pesantren. The mosque is the central building of a pesantren. Compared to other buildings, a mosque is a multipurpose place that is always crowded or at most the center of activities of pesantren residents. The mosque has the primary function for the place of performing congregational prayers and worship. ${ }^{12}$ The mosque became the first building when Kyai establishes a pesantren and it is always located near his house. This is done because the position of the mosque as an educational center in the Islamic tradition is a manifestation of universalism from the traditional Islamic education system, which is currently also adopted by modern Islamic education.

\footnotetext{
${ }^{11}$ Zamakhshari Dhofier, Tradisi Pesantren: Studi Tentang Pandangan Hidup Kyai (Jakarta: LP3ES, 1985); Zakaria, “Pondok Pesantren: Changes and Its Future"; Florian Pohl, "Islamic Education and Civil Society: Reflections on the Pesantren Tradition in Contemporary Indonesia," Comparative Education Review 50, no. 3 (2006): 389-409, http://www.journals.uchicago.edu/doi/10.1086/503882; Syamsul Ma'Arif, "Education as a Foundation of Humanity: Learning from the Pedagogy of Pesantren in Indonesia," Journal of Social Studies Education Research 9, no. 2 (2018): 104-123.

12 Imam Bawani, Tradisionalisme Dalam Pendidikan Islam (Surabaya: Al Ikhlas, 1993), 91-92.
} 
The term of "santri" has two connotations or meanings. First, those who obey the command of the Islamic religion or, in other words, are often referred to as "Orthodox Muslims." The term "santri" is contrasted in contrast to the abangan group, namely people who are more influenced by pre-Islamic Javanese cultural values, especially values derived from Hindu and Buddhist mysticism. ${ }^{13}$ Second, people who are studying in pesantren educational institutions. Both are different, but the similarity is also clear, which is equally obedient in carrying out Islamic law. ${ }^{14}$ The students who study in one cottage usually have a strong sense of solidarity and kinship both between students and students and between students and Kyai. The social situation that developed among the santri fostered a separate social system, in the pesantren they learned to live in society, organize, lead, and be led, and were also required to be able to obey and emulate the life of the kyai, in addition to being willing to carry out any task given by the kyai, this is possible because they live and live in a complex. ${ }^{15}$

Teaching classical religious books one feature that distinguishes pesantren from other educational institutions is the teaching of classical religious books in Arabic, or more popularly called the "yellow book". Although now, with the various reforms carried out in the pesantren by including teaching public knowledge as an essential part in pesantren education, teaching of classical Islamic books, especially essays of scholars who adhere to the Shafi'i ideology is still given in the pesantren as an effort to continue the primary purpose of the pesantren, namely, to educate prospective scholars, who are loyal to traditional Islamic ideology. ${ }^{16}$

The existence of Kyai in the pesantren environment is an essential element because he was the one who pioneered, established, managed, nurtured, led, and sometimes also as the sole owner of a pesantren. Therefore, the growth of a pesantren is very dependent on the ability of his kyai, so naturally, we see that many pesantren that have dispersed, because of the death of his kyai, while he has no descendants who can continue his leadership.

On charisma describing, Weber's conception was morality-free and more about the existence of the charisma than about making personal value judgments. He writes in the book that "charisma does not know of any formal and controlled referral or rejection, career, advancement or salary, supervisory or appeal authority, local or purely technical jurisdiction, and perpetual institutions in the manner of bureaucrat agencies." Charismatic leaders are savior-like, and people follow them as they are thought to put things right. ${ }^{17}$

\footnotetext{
${ }^{13}$ M. Dawam Rahardjo, Pergulatan Dunia Pesantren: Membangun Dari Bawah (Jakarta: Perhimpunan Pengembangan Pesantren dan Masyarakat (P3M), 1985), 37.

${ }^{14}$ Bawani, Tradisionalisme Dalam Pendidikan Islam, 93.

${ }^{15}$ Abuddin Nata, "Pendidikan Islam Di Era Milenial," Conciencia 18, no. 1 (2018): 10-28; Nurcholis Madjid, Bilik-Bilik Pesantren: Sebuah Potret Perjalanan (Jakarta: Penerbit Paramadina, 1997).

${ }^{16}$ Toto Suharto, "Transnational Islamic Education in Indonesia: An Ideological Perspective," Contemporary Islam 12, no. 2 (2018): 101-122; Ismail Suardi and Sanusi Hamid, "Technology on Language Teaching and Learning : A Research on Indonesian Pesantren," Procedia - Social and Behavioral Sciences 83 (2013): 585-589, http://dx.doi.org/10.1016/j.sbspro.2013.06.111.

${ }^{17}$ Max Weber, The Theory of Social and Economic Organization (New York: The Free Press, 1966).
} 
Naufal Ahmad Rijalul Alam

Charismatic leadership concentrates on the three elements of Weber's theory. There is a psychological dimension to the internal quality of the leader. Weber describes the concept of being a "gift" of the leader, stating that it could be either a spiritual attribute or a physical or mental state of being. But since Weber's theory of charisma is value-free and based on the perceptions of the superiors, there is no clear explanation of the origins of charisma.

The second dimension refers to the social aspect. Charismatic leadership may not be based solely on one's inner self but on a social basis. This could be the cultural influence of language, family, work, or even education. By essence, Charisma takes on a traditional form and legitimizes its roots. The impersonal aspect of the faith implies that, according to Weber, it could be taught. ${ }^{18}$

Ultimately, Weber's theory also has a psychological dimension between the ruler and the subservient. According to Weber, charisma is the "affective connection between leader and follower that evolves as the historical result of contact between person and circumstance." To continue to enjoy credibility, the leader must demonstrate his or her importance and charisma. Charismatic leadership is therefore relational, as subordinates will withdraw their support, causing the leader to rule without authority. ${ }^{19}$

Curiously, Weber's charismatic leader had his death, and the valid authority of the charismatic leader was something he did not think he could have endured. This was because the structure in which it worked has shifted and the traditional justification for the control behind it had been weakened. According to Weber, charismatic leadership would be challenging to routine, causing problems throughout the transition of corporation or the state. ${ }^{20}$

\section{Charismatic Leadership Characters of Kyai Teguh}

The word kyai is quite popular with the community of Santri. The kyai is the main pillar of the life of the pesantren, not only because the kyai is the main role in the consistency of the schooling system in the pesantren, but also because the kyai figure reflects the values that live in the pesantren atmosphere. The position and influence of the kyais lie in the virtues of the private kyais, namely the mastery and depth of religious knowledge, piety reflected in daily attitudes and behavior which at the same time reflects living values and are characteristic of pesantren. This is what makes the growth of a pesantren solely depending on the ability of his kyai's personality.

According to its origin, the term kyai in Javanese is used for three different types of titles: (a) an honorary degree for subjects reflected on sacred; for example, "Kyai Garuda Kencana" is used as a gold

\footnotetext{
${ }^{18}$ Ferry Muhammadsyah Siregar, Nur Kholis Setiawan, and Robert Setio, "Religious Leader and Charismatic Leadership in Indonesia: The Role of Kyai in Pesantren in Java," Jurnal Kawistara 3, no. 2 (2013): 140-152.

${ }^{19}$ Max Weber, Economy and Society I (Los Angeles: University of California Press, Berkeley, 1978); Weber, The Theory of Social and Economic Organization.

${ }^{20}$ Arifin, "Charisma and Rationalisation in a Modernising Pesantren : Changing Values in Traditional Islamic Education in Java"; Robert J. House and Jane M. Howell, "Personality and Charismatic Leadership," The Leadership Quarterly 3 no. 2 (1992): 81-108.
} 
train in the Sultan's Palace; (b) as an honorary degree for the elderly in general; and (c) as a religious name to an Islamic scholar who owns or is the leader of the pesantren and teaches Islamic theology. ${ }^{21}$

Of the three types mentioned above, the three seem to be the most appropriate title for the pesantren leader. At least Kyai has the characteristics of being a central figure in the pesantren community because of his authority and charisma, ${ }^{22}$ the most religious figure and high spiritual ability, avoiding badness and disobedience, ${ }^{23}$ and always living and meditating on God's verses which are then taught to his students. ${ }^{24}$

As a leader, Kyai needs to be having the strength of leadership style in managing the whole of pesantren activities, academic or non-academic. By this, charismatic leadership is appropriate to Kyai, because the style is a type of leadership that instills ideological values by better articulating organizational visions. ${ }^{25}$ The values conveyed then affect the emotions of members so that these values are applied by their members. ${ }^{26}$ At this time, on pesantren Bina Insani, charisma defines because of the perception of followers of Kyai Teguh who is influenced by the actual abilities and behavior of him. Therefore, he can interplay the circumstances that happen in his society.

Charismatic leadership is a model used by scholars and business leaders to assess which features, behaviors and practices help to encourage and promote change in the workplace, including the academic environment. Many paradigms and hypotheses have been created by those studying the subject to help educate and informs educational leaders about the most efficient management tools and methods. These notions involve self-assessment systems, connections from others, and visionary governance. ${ }^{27}$ Many types of leadership are applied by a leader, but according to Achua $\&$ Lussier ${ }^{28}$ charismatic leadership is a style that has an extraordinary influence on its members. The great influence of charismatic leadership is being able to change members' focus from personal focus to collective focus.

As shown by House ${ }^{29}$ and Shamir et al., ${ }^{30}$ charismatic behavior has a number of characteristics as follows: (1) articulating a philosophic vision that defines a brighter future state in terms of ideas such as human rights, stability, prosperity, justice, fairness, and the achievement of the position and

\footnotetext{
${ }^{21}$ Dhofier, Tradisi Pesantren: Studi Tentang Pandangan Hidup Kyai.

${ }^{22}$ Saiful Akhyar Lubis, Konseling Islami Kyai Dan Pesantren (Yogyakarta: eLSAQ Press, 2007); Abdullah Syukri Zarkasyi, Gontor Dan Pembaharuan Pendidikan Pesantren (Jakarta: Raja Grafindo Persada, 2005).

${ }^{23}$ Hamdan Rasyid, Bimbingan Ulama; Kepada Umara Dan Umat (Jakarta: Pustaka Beta, 2007); Sukamto, Kepemimpinan Kiai Dalam Pesantren (Jakarta: LP3ES, 1999).

${ }^{24}$ Nurhayati Djamas, Dinamika Pendidikan Islam Di Indonesia Pasca Kemerdekaan (Jakarta: Raja Grafindo Persada, 2008).

${ }^{25}$ Delbecq et al., "Implicit Motives, Leadership, and Follower Outcomes: An Empirical Test of CEOs."

${ }^{26}$ Shamir, House, and Arthur, "The Motivational Effects of Charismatic Leadership : A Self-Concept Based Theory."

${ }^{27}$ Arifin, "Charisma and Rationalisation in a Modernising Pesantren : Changing Values in Traditional Islamic Education in Java"; Jane M. Howell and Boas Shamir, "The Role of Followers in the Charismatic Leadership Process: Relationships and Their Consequences," Academy of Management Review 30, no. 1 (2005): 96-112.

${ }^{28}$ Achua and Lussier, Effective Leadership.

${ }^{29}$ Robert J. House, “A 1976 Theory of Charismatic Leadership," in Leadership: The Cutting Edge, ed. J.G.Hunt and L.L.Larsen (Carbondale IL: Southern Illinois University Press, 1977).

${ }^{30}$ Shamir, House, and Arthur, "The Motivational Effects of Charismatic Leadership : A Self-Concept Based Theory."
} 
Naufal Ahmad Rijalul Alam

freedoms assumed to be the moral right of followers; (2) referencing distal rather than substantive objectives; (3) exchanging messages often relating to beliefs and moral justifications, to personal and collective identities, and the significance and effectiveness of adherents as individuals and as a group; (4) the interpersonal role modeling of values suggested in the vision by a personal example; (5) presenting high-performance expectations of followers; (6) the transmission of a high degree of confidence in the capacity of followers to meet these expectations; and (7) showing of behaviors that selectively give rise to implicit accomplishment, power, and the affiliation of followers when these motives are different.

These charismatic leaders have a quality that is hard to pin down, but that attracts followers and inspires people to act. Transformation leaders are often extremely charismatic because they can initiate and handle a large level of change in the organization. Charismatic leaders have a powerful influence on their subordinates. They believe that everything the leader does is right, has no mistakes; there is an emotional attachment, and the contribution made is thanks to the guidance given wholeheartedly by the leader. ${ }^{31}$ In general, charismatic leaders have high self-confidence, the charisma that can direct, and are always admired by others, both from the way they talk, the gestures, to the ideas that are raised. This element makes the leader has an ideal vision and goals so that it is easy to influence the surrounding community.

\section{Figure 1. The Seven Character of Charismatic Leadership}

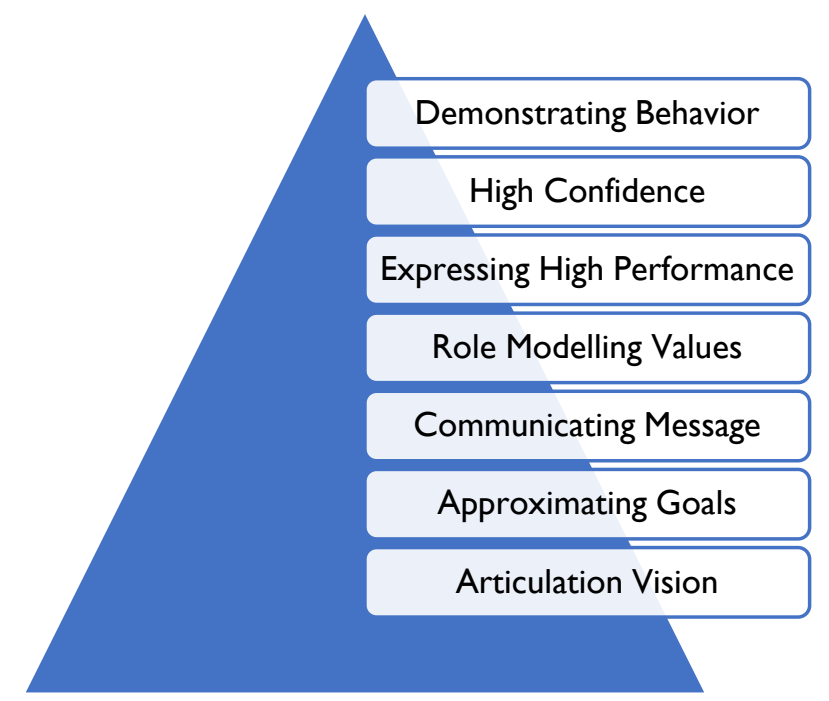

In society, Kyai is part of an elite group in the social, political, and economic structure, which has a powerful influence on society, usually, they have a prominent position at both the local and national level. Thus, the Kyai is an effective decision-maker in the social life system, not only in religious life but also in political matters. With their superior knowledge in the field of religion, the Kyai are often regarded as people who can always understand the majesty of God and the secrets of nature so that they are considered to have a position that is unreachable by layman's culture, or in terms commonly

\footnotetext{
${ }^{31}$ House, “A 1976 Theory of Charismatic Leadership."
} 
called "Kyai khos" so that in some cases they show their specificity in the form of clothing such as skullcaps and turban and robes as a symbol of wisdom. In the pesantren environment, a Kyai is the only power hierarchy that is upheld above moral authority as a savior of the santri from the possibility of stepping into error, this power has an absolute disposition so that the santri is always bound to his kyainya for life, at least as a source of inspiration and as support moral in his personal life.

As the explanation above, I tend to use the charismatic leadership theory to describe Kyai Teguh himself in managing the organization of educational institution based on Boje's theory ${ }^{32}$ on charismatic leadership such as, people are trust in him and his revelation, choose members or staffs not for technical training but based on social privilege and the paramount aspect is he preaches, creates, and demands new obligations in all daily, monthly, and annually activities. Herinafter, to engage the theory and answering the research problem I collected the data from respondents, by using interview and FGD sessions, as well as in classroom observations. The charismatic leadership characteristic of Kyai Teguh in pesantren Bina Insani in Yogyakarta was categorized into seven major themes including (1) articulating vision, (2) approximating goals, (3) communicating message, (4) role modeling values, (5) expressing high performance, (6) high confidence, and (7) demonstrating the behavior.

\section{Articulating Vision}

Based on the interviews and FGDs data, my respondents reported that the Kyai is adept at conveying the vision of the pesantren, including how to socialize that vision. The capability Kyai's explaining in every single activity is apprehended teachers, students, and staffs to the goal of pesantren in the teaching and learning process, including non-academic program. For example, R1 and R3 reported,

I felt that Kyai always delivering the vision through three ways: pictures, verbal repetition at every opportunity, and internalization through assignments, the first and second ways are the most effective by me (R1)

In academic culture, the vision is conveyed in every subject matter or study conducted by the Kyai, as well as the Kyai himself (R3)

In the observation sessions, students in pesantren Bina Insani obtained the very detailed exegesis of vision delivered by Kyai Teguh, for 24 hours a week in every activity. For instance, after Maghrib prayer, Kyai Teguh in giving preaching always insert the importance of vision in pesantren system which all residents of pesantren can deal with it. In the class or non-academic participation, they seemed to understand and sure with the vision. It is similar to the result of the interview where the respondents revealed the same stories.

\footnotetext{
32 David M. Boje, "Transformational Leadership," last modified 2000, https://business.nmsu.edu/ dboje/teaching/338/transformational_leadership.htm.
} 
Naufal Ahmad Rijalul Alam

\section{Approximating Goals}

The second theme is related to Kyai's understanding on achieving pesantren goals. Achieving goals that are in line with the vision of the pesantren is needed by Kyai to uniform programs and results accordingly, therefore Kyai always provides inspires his subordinates in the form of advice and concrete examples. When I did the observation, some students tidy the stuff of store belongs to pesantren. Following their statement, pesantren needs to financial sourcing to supply their necessary. By this, kyai Teguh hand over his trust for the oldest students in managing the store, as conveyed by R4 and R5:

In my view, Kyai always persuades pesantren residents to be willing and confident in carrying out their tasks, both individual and group (R4)

Every task given by Kyai is not uncommon in obstacles. In this case, the Kyai always gives high trust and respect for the results given by his subordinates, including me (R5)

According to the data presented above, in coping with the goals of pesantren, both respondents tended to get trust from kyai to settle every job they did. From this trust, both felt confident and have enthusiasm in conduct and finish the duty in a good condition, and sometimes the impact is gratified than previous.

\section{Communicating Message}

The next major was related on how Kyai has well communication for delivering his message to his follower. One character that necessary for Kyai as a caregiver in pesantren is how he contributes as a linker from his knowledge and then transmits to their students as well as teacher or follower. The ability of Kyai in communicating and delivering a message will enhance trust and confidence, so it means for those involved directly with Kyai. This is in line with the clarification of R2, R8, and R9 as follows:

In communicating, Kyai has always applied the principle of meaningfulness, which is related to the values of pesantren. As a highly respected figure, advice from Kyai is always needed by me, so that in my daily life, Kyai always inserts important values that are transformed by actions (R2)

I guess communication becomes the dominant factor that makes Kyai respected and heard every word. Therefore, there must be consistency between speech and action, so that it can be an example for pesantren residents (R8)

Kyai's voice intonation often becomes a magnet for teachers and students. For example, when a Kyai talks, people around him will be quiet and listen (R9)

The results of the interview on R2 shows that the Kyai and the students have a very strong relationship, both in the teaching and learning process and in the assignment. Kyai as a communicator has a huge influence in changing attitudes and giving value to students. The communication built by the Kyai also has the aim of creating a reciprocal relationship between the two as conveyed by R8. Because in pesantren, Kyai is not only a teacher but also a parent. Good attitude and communication will create 
a familiar atmosphere and the need to help each other continuously. Thus, according to R9, everything that comes out of the Kyai's mouth will be heard by his students.

\section{Role Modelling Values}

As an educational institution that focuses on forming the mental and character of students so that they can answer the challenges of the times, as well as to maintain the administrative rhythm of the pesantren to survive, a leader who can be a role model for his subordinates is very much needed, who can be an example or an example for those they lead. This role model or example is important because it will be a magnet for the subordinates, they lead to follow and do what the leader wants, as R6 and R7 said:

Some models are shown by Kyai to recognize the values of pesantren toward teacher and santri. It is starts from his character and personality in doing activities (R6)

The kyai always prioritize the interests of the pesantren compared to his own or the interests (R7)

One of the most important values that will be confirmed by pesantren residents is the role model of Kyai. He is not only a caretaker of the pesantren but is also directly involved in providing a good charismatic example to their students. The kyai at the Bina Insani Islamic boarding school is the central figure of all activities carried out. He directly monitors the field to provide support so that all pesantren activities run smoothly. Exemplary is a way that is always given by Kyai in caring for students by giving assignments as well as providing examples. Modeling occupies a strategic position in caring for the students because the students will imitate all their behavior.

\section{Expressing High Performance}

Performance is one of the most physical appearances of Kyai that draw the attention of santri in every single duty, even if Kyai did common work as his job usually, like teaching, giving a word, and so on.

In his daily life, Kyai shows high performance in terms of appearance, clothing, to facial mimics that always look fresh. This has a good effect on the students and teachers who see it (R10)

The high performance of Kyai is also shown when entertaining guests or giving recitals in front of the community. Good body structure and good communication methods make Kyai has a good example (R3)

At pesantren Bina Insani, Kyai Teguh seems to show high performance when he met with the staff, santri, or teacher in his daily life. Physical appearance shown by him including uniform and facial mimic or gesture eventually influence those who met him. Once the guest comes to the pesantren, this character needs at least in communicating and offers the idea or introduce pesantren to others. When 
Naufal Ahmad Rijalul Alam

he meets to the community in several activities, this gesture must be shown so people enthusiastic and interest in his speech. For this, Kyai has become a good example for the people around him.

\section{High Confidence}

The most character refers to santri on their capability after graduation and most seeing by the community is their confidence in facing the new conditions.

When the teachers and students have academic or administrative problems, Kyai does not blame, but tries to solve the problem together. This turned out to foster high confidence among teachers and students in breaking down the problem at hand (R5 and R8)

Kyai empowering pesantren is done by making everyone responsible for their respective tasks, be it teachers, staff, or students (R2 and R7)

A good leader always instills and builds self-confidence, especially when facing problems. Thus, self-confidence will emerge by itself when leaders trust their subordinates or members that they have the ability and responsibility for their work. This belief in the end will give legality to the Kyai that the students, teachers, and society are willing to respect and obey all the rules that have been set.

\section{Demonstrating Behaviour}

The figure of Kyai as a leader has power and authority which is shown in each of his behavior to direct and empower the potential in the human community, he leads so that the goals he aspires to be achieved together. In other words, the Kyai in the social structure of the pesantren functions as a regulator and supervisor so that collective goals can be achieved as stated by R1, R4, R6, and R10:

The three characters that Kyai Teguh always shows are assertiveness, accuracy, and attention, both in academic and non-academic terms (R1 and R4)

Once a week the Kyai always advises his students in motivational activities. Not infrequently he invited colleagues from both the pesantren and the public to transform the noble values of Education in the pesantren (R6 and R10)

This last character emphasizes the position of kyai Teguh in providing a positive example to the pesantren community in carrying out academic and non-academic activities. This character also shows the importance of building intimacy that must be raised to others so that the results that are done can be maximized.

\section{Discussion}

The circumstances at pesantren Bina Insani are in line with Weber's charismatic leadership theory, which is based on three aspects: the psychological quality of the leader, the psychological 
dimension between superiors and sub-ordinates and, finally, the social dimension. ${ }^{33}$ The psychological quality of leader in current situation is the ability to express the vision, encourage vision values, and promote a positive environment in which everyone can fulfill the goals of the organization and satisfy their personal needs. ${ }^{34}$ Evidence has shown that a clear and consistent vision can attract more human attention than charisma. Even the leader does not have the most charismatic, good-looking, and persuasive man, but if they have a clear vision and people believe in it, they will become the leader of the people. Vision provides the institutional participants a sense of balance and believes the method of convincing others to work towards a common goal to be important for leadership.

A good vision is always closely linked to organized management, that is to admit, the pesantren decide to hold out formal internal and external management, but still have full policies adopted by Kyai as a leader. However, in Bina Insani, in managing the pesantren, kyai Teguh always involves input and opinions from other people, particularly from the staff, ustadz, and not infrequently and not infrequently from community leaders. It is due to, the education on pesantren Bina Insani has been known as community-based education, derived from the aspirations of the community, and to meet the interests them. As a community-based educational institution, pesantren become very dependent on the initiative and charisma of the kyais who become leaders. The pesantren has become very diverse and identical to the personal vision of the caregiver kyai. Although diversity is a treasure in a democratic society, on the other hand, it can produce different interpretations of the functions and objectives of pesantren.

The existence of pesantren Bina Insani as an Islamic education cannot be separated from the presence of five main elements: kyai as leaders and caregivers, santri, mosques as centers of worship and education, learning methods, and dormitories as places of education. Kyai Teguh, as a leader in pesantren Bina Insani is responsible to integrated five elements with his capability. Furthermore, Kyai's vision is in harmony with the ideology of the Bina Insani pesantren and the educational context it carries. From the explanation above, I conclude that the doctrine of education in the Bina Insani pesantren is to form reliable and robust santri in the religious field as a form of values formulated in the vision of education, which championed in pesantren learning activities programs. With other languages spelled out in the boarding school education curriculum.

Based on the interview, the psychological dimension between superiors and sub-ordinates, including social dimension practices of kyai Teguh has five main functions. First, Instruction functions as one-way communication. Kyai Teguh is a leader who determines what, how, when, and where the order is done so that decisions are implemented effectively. Effective leadership requires the ability to push and inspire others to want to follow orders. Second, consulting is two-way communication. In the first

\footnotetext{
${ }^{33}$ Siregar, Setiawan, and Setio, "Religious Leader and Charismatic Leadership in Indonesia: The Role of Kyai in Pesantren in Java."

${ }^{34}$ Boje, "Transformational Leadership."
} 
Naufal Ahmad Rijalul Alam

stage of the choice-making process, Kyai Teguh often needs material consideration that requires him to consult with the people he leads, who are considered to have a variety of information materials needed in the decision-making process. The next stage of consultation by the leadership of the people led maybe practice after the decision has been taken and is being taken. The purpose of the consultation was to obtain input in the form of feedback to improve and make perfect decisions that have been identified and implemented.

Third, the function of participation. In carrying out this function, Kyai Teguh seeks to activate the people he leads, both by engaging in and implementing decisions. Participation does not mean free to do everything but carried out in a guided and driven mode of collaboration, without intervention or taking on the important tasks of others. The participation of the leader must continue as a leader, not a compiler. Fourth, the delegation role is to be carried out by the delegated authority to make or assess decisions, either by approval or without the approval of the leadership. The function of delegation means trust. The beneficiaries of the delegation must be believed to be Kyai Teguh assistants who share the same principles, perceptions, and aspirations. Five, control functions mean that successful leadership practices operated by Kyai Teguh can govern the activities of its members in a coordinated and ineffective manner to achieve the full shared objectives. The control function can be carried out through guidance, direction, coordination, and supervision activities.

All leadership functions are carried out in leadership activities integrally, namely, the leader is obliged to describe the work program, be able to provide clear instructions, try to develop freedom of thought and issue opinions, develop harmonious cooperation, be able to solve problems and make problem decisions according to the limits of their respective responsibilities, fostering the ability to assume responsibility, and the leader must utilize supervision as a controlling tool. The main characteristic of this character is that Kyai in leading the pesantren always shows enthusiasm in all activities. This is supported by his ability to control, deliver tasks, and give responsibilities to his subordinates, both teachers, staff, and students. The assignment of tasks is accompanied by examples of how they are carried out to minimize unfavorable results. Thus, the factor is not a problem because all elements of the pesantren know their respective duties.

Kyai's Teguh vision and mission emphasize aspects of strengthening the Education base, especially for the poor, and orphans. This strengthening is supported by the generosity of the people who take part in the economic aspects of the pesantren to be able to finance all the needs of underprivileged students. The commitment given by the Kyai is evident from his performance and productivity. Both affect the ethics and morals of pesantren residents so that in their implementation, the Kyai only provides stimulus and supervision to assess the quality of an activity. Kyai becomes a respected figure in the community, especially relating to the religious field. More than that, Kyai as central in various community activities, in this case, if the community gets a problem, in any case, they always consult the Kyai to find a solution. Kyai's guidance consists of five aspects, creed, morals, date 
(history), worship, and general science. With this guidance, the education process does not only lead to students, but also religious teachers, and even the involvement of surrounding communities is also quite high.

In pesantren, leadership means a lot of things. This is due to the changing character of leadership in different roles in different settings, beginning with family leadership in top positions in global organizations. The fundamentals of leadership, however, are the same for all leaders in all situations. Nevertheless, different leaders have different perceptions of leadership due to the variety of skills needed, roles are undertaken, tasks performed, topics addressed, and relationships fostered. As such, there have been many strengths in the type of resources and procedures, and the attributes and types of leadership for success and failure in leadership. Nevertheless, even these attributes cannot provide enough guidelines for the success of leadership. As a result, leadership theorists and practitioners have gone so far as to establish a contingency strategy,' which stresses that there is no better way.

Finally, this research also has a limitation, mainly many of the figures who helped found the pesantren have died, so it is rather difficult for me as a researcher to know the details of Kyai's firm profile at the beginning of his leadership, both in terms of quality, the influence he has, and the effectiveness of his performance. Even so, I still have the ability to communicate with local community leaders who have followed the development of the pesantren from its establishment until today.

\section{E. Conclusion}

Based on the findings and discussion of this study, it can be concluded that kyai Teguh has a distinctive charismatic personality towards students, teachers, and residents. There are at least four indicators that support it. First, the kyai Teguh has a strong and futuristic vision. In its implementation, he uses the method of assignment, reinforcement through images, and always repeating it in daily communication, both through teaching, gathering, and recitation. Second, the purpose of the pesantren that supports the vision is well implemented by kyai Teguh by giving full trust to both internal and external elements of the pesantren. Third, besides giving assignments, Kyai Teguh is also able to be a good role model and example for his subordinates. Not only governing, but he also gave a way to do the job accurately and efficiently. It provides a positive change to his subordinates. Fourth, the communication delivered by the kyai can influence his listeners. Even the community always makes the kyai as a place to ask questions related to matters relating to religious and social norms. Fifth, the charisma shown by the kyai is not only in terms of appearance, voice, and gesture but also in decision making with a high level of trust, so the community and members of the pesantren do not have the slightest doubt to follow the words of the kyai. 


\section{F. References}

Achua, C. F., and R. N. Lussier. Effective Leadership. 5th ed. Ohio: South Western, 2013.

Ahsan, Muhamad, Armanu Thoyib, Achmad Sudiro, and Nur Khusniyah Indrawati. "Developing Entrepreneurial Spirit Based on Local Wisdom." International Journal of Social Science Research 4, no. 2 (2016): 44.

Alam, Naufal Ahmad Rijalul. "Strengthening Leadership Culture: The Role of Kyai in Indonesian Pesantren." At-Ta'dib 13, no. 1 (2018): 5-17.

Arifin, Achmad Zainal. "Charisma and Rationalisation in a Modernising Pesantren : Changing Values in Traditional Islamic Education in Java" (2013): 97. http://researchdirect.uws.edu.au/islandora/object/uws\%3A17130/.

Bartoletti, JoAnn, and Gail Connelly. Leadership Matters: What the Research Says About the Importance of Principal Leadership. National Association of Secondary School Principals and National Association of Elementary School Principals. Virginia, 2013.

Bawani, Imam. Tradisionalisme Dalam Pendidikan Islam. Surabaya: Al Ikhlas, 1993.

Bennett, Nigel, and Lesley Anderson. Rethinking Educational Leadership: Challenging the Conventions. SAGE Publications, 2003.

Blumberg, A., and W. Greenfield. The Effective Principal: Perspectives on School Leadership. Boston: Allyn and Bacon, Inc, 1980.

Boje, David M. "Transformational Leadership." Last modified 2000. https://business.nmsu.edu/ dboje/teaching/338/transformational_leadership.htm.

Delbecq, Andre, Robert J. House, Mary Sully de Luque, and Narda R. Quigley. "Implicit Motives, Leadership, and Follower Outcomes: An Empirical Test of CEOs." Journal of Leadership and Organizational Studies 20, no. 1 (2013): 7-24.

Dhofier, Zamakhshari. Tradisi Pesantren: Studi Tentang Pandangan Hidup Kyai. Jakarta: LP3ES, 1985.

Djamas, Nurhayati. Dinamika Pendidikan Islam Di Indonesia Pasca Kemerdekaan. Jakarta: Raja Grafindo Persada, 2008.

Fiedler, Fred E. A Theory of Leadership Effective. New York: Mc. Gwar-Hill Book Company, 1964.

Hassel, Emily Ayscue, and Bryan C. Hassel. "An Excellent Principal for Every School." Public Impact (2016): 1-16.

House, Robert J. "A 1976 Theory of Charismatic Leadership." In Leadership: The Cutting Edge, edited by J.G.Hunt and L.L.Larsen. Carbondale IL: Southern Illinois University Press, 1977.

House, Robert J., and Jane M. Howell. "Personality and Charismatic Leadership." The Leadership Quarterly 3, no. 2 (1992): 81-108.

Howell, Jane M., and Boas Shamir. "The Role of Followers in the Charismatic Leadership Process: Relationships and Their Consequences." Academy of Management Review 30, no. 1 (2005): 96-112.

Judge, T. A., R. F. Piccolo, and T Kosalka. "The Bright and Dark Sides of Leader Traits: A Review and Theoretical Extension of the Leader Trait Paradigm." The Leadership Quarterly 20 (2009): 855-875.

Lubis, Saiful Akhyar. Konseling Islami Kyai Dan Pesantren. Yogyakarta: eLSAQ Press, 2007.

Ma'Arif, Syamsul. "Education as a Foundation of Humanity: Learning from the Pedagogy of Pesantren in Indonesia." Journal of Social Studies Education Research 9, no. 2 (2018): 104-123.

Madjid, Nurcholis. Bilik-Bilik Pesantren: Sebuah Potret Perjalanan. Jakarta: Penerbit Paramadina, 1997.

Miles, Matthew B., A. Michael Huberman, and J. Saldana. Qualitative Data Analysis: A Method Sourcebook. 3rd ed. USA: SAGE Publications, 2014.

Muflichah, Siti. "The Charisma Leadership Style of Kyai Haji Arwani Amin The Founder of Yanbuul Quran Pesantren, Kudus." Journal of Islamic Civilization in Southeast 03, no. 01 (2014): 61-81. http://journal.uin-alauddin.ac.id/index.php/jicsa/article/view/774.

Nata, Abuddin. "Pendidikan Islam Di Era Milenial." Conciencia 18, no. 1 (2018): 10-28.

Peters, MIchael A. Encyclopedia of Educational Philosophy and Theory. Encyclopedia of Educational Philosophy and Theory, 2017. http://link.springer.com/10.1007/978-981-287-588-4.

Pohl, Florian. "Islamic Education and Civil Society: Reflections on the Pesantren Tradition in Contemporary Indonesia." Comparative Education Review 50, no. 3 (2006): 389-409. http://www.journals.uchicago.edu/doi/10.1086/503882.

Rahardjo, M. Dawam. Pergulatan Dunia Pesantren: Membangun Dari Bawah. Jakarta: Perhimpunan 
Pengembangan Pesantren dan Masyarakat (P3M), 1985.

Ramli, Muhamad. "Manajemen Dan Kepemimpinan Pesantren: Dinamika Kepemimpinan Kiai Di Pesantren." Al Falah 17, no. 2 (2017): 125-162.

Rasyid, Hamdan. Bimbingan Ulama; Kepada Umara Dan Umat. Jakarta: Pustaka Beta, 2007.

Sahin, Abdullah. "Critical Issues in Islamic Education Studies: Rethinking Islamic and Western Liberal Secular Values of Education." Religions 9, no. 11 (2018).

Shamir, Boas, Robert J. House, and Michael B. Arthur. "The Motivational Effects of Charismatic Leadership : A Self-Concept Based Theory." Organization Science 4, no. 4 (1993): 577-594.

Siregar, Ferry Muhammadsyah, Nur Kholis Setiawan, and Robert Setio. "Religious Leader and Charismatic Leadership in Indonesia: The Role of Kyai in Pesantren in Java." Jurnal Kawistara 3, no. 2 (2013): 140152.

Suardi, Ismail, and Sanusi Hamid. "Technology on Language Teaching and Learning : A Research on Indonesian Pesantren." Procedia - Social and Behavioral Sciences 83 (2013): 585-589. http://dx.doi.org/10.1016/j.sbspro.2013.06.111.

Subagja, Soleh. "PARADIGMA NILAI-NILAI KEPEMIMPINAN PROFETIK (Spirit Implementasi Model Kepemimpinan Di Lembaga Pendidikan Islam)." Progresiva 3, no. 2 (2010): 23-42.

Suharto, Toto. "Transnational Islamic Education in Indonesia: An Ideological Perspective." Contemporary Islam 12, no. 2 (2018): 101-122.

Sukamto. Kepemimpinan Kiai Dalam Pesantren. Jakarta: LP3ES, 1999.

Syamsuriadi. "Self Management Concept Dalam Kepemimpinan Lembaga Pendidikan." Adaara: Jurnal Manajemen Pendidikan Islam 9, no. 2 (2019): 871-879.

Weber, Max. Economy and Society I. Los Angeles: University of California Press, Berkeley, 1978.

- - - The Theory of Social and Economic Organization. New York: The Free Press, 1966.

Winarko, Bambang. "Content, Benefits and Development of Pesantren Online in Indonesia." Malaysian Journal of Library \& Information Science 12, no. 2 (2007): 57-75.

Zakaria, Gamal Abdul Nasir. "Pondok Pesantren: Changes and Its Future." Journal of Islamic and Arabic Education 2, no. 2 (2010): 45-52.

Zarkasyi, Abdullah Syukri. Gontor Dan Pembaharuan Pendidikan Pesantren. Jakarta: Raja Grafindo Persada, 2005. 
Naufal Ahmad Rijalul Alam 